\title{
A SZOFTVERFEJLESZTÉSI FOLYAMAT ÁTFOGÓ ÉSZSZERÜSÍTÉSE A VÁLLALATI DINAMIKUS KÉPESSÉGEK LENCSÉJÉN KERESZTÜL
}

A dinamikus képességek elmélete a szervezeti megújulásra, észszerűbb erőforrás-felhasználásra és a hatékonyabb működés elérésére irányul. Jelen cikk fő célja egy magyar KKV szoftverfejlesztési projektjén belül a működésben lényeges szerepet betöltő kiadási folyamat elemzése. Az elemzett vállalat termékfejlesztési folyamata lassú és következetlen volt, amelyre megoldást kellett találni. A szerzők munkájukban egy agilis, ezen belül is egy ún. Scrum fejlesztési módszer bevezetését követik nyomon, amely dinamikus képességek tulajdonságával bír, és megváltoztatja a megfigyelt szervezet működési beidegződéseit a hatékony működés érdekében. Kutatásuk megmutatta, hogy a Scrum módszertan alkalmazása jelentősen csökkenti a szoftverfejlesztési folyamat átfutási idejét és teljes költségét, hozzájárulva a vállalati teljesítmény javításához. Végeredményben a tanulmányozott szervezet növelte stratégiai mozgásterét, valamint elégedettebbé tette belső és külső érintettjeit az új folyamat bevezetését követően. A célvállalat átalakulását az akciókutatás módszerével követik nyomon, amely együttműködést feltételez a kutatók és a szervezet tagjai között a valós probléma azonosítása, a megoldás kimunkálása és bevezetése érdekében.*

Kulcsszavak: dinamikus képesség, szoftverfejlesztési projekt, Scrum, akciókutatás

A dinamikus képesség fogalma a szervezet azon képességét ragadja meg, amely a változó piaci viszonyok közepette képessé tesz a megújulásra, az erőforrások észszerübb kezelésére és a hatékonyabb müködési képesség biztosítására (Bohl, 2015; Teece et al., 1997; Stadler et al., 2013; Winter, 2003). A müködési, azaz nem dinamikus képességekkel szemben, amelyek a belső folyamatok állandóságát, a kiegyensúlyozott napi üzletvitelt biztosítják, a dinamikus képességek alkalmazása új eljárásokat és folyamatokat tesz lehetővé (Helfat - Winter, 2011). Ezek irányulhatnak jelenlegi vagy új termékekre és szolgáltatásokra, illetve egyazon vagy új fogyasztói kör számára (Helfat - Winter, 2011). Az elmélet szerint - a túlélés és a versenyképességi előny érdekében - a kiemelkedő dinamikus képességgel rendelkező vállalatokat vállalkozói szemlélet hatja át, testet öltve a lehetőségek észlelésében, megragadásában, a vevői igényekhez való igazodásban és a fejlődéssel kapcsolatos elvárásoknak való megfelelésben (Teece, 2007).

Az elmélettel foglalkozó szakirodalom azonban nem ad választ arra, hogy a vállalatok miképpen fejlesztik ki e komplex és heterogén képességeket. Továbbá egyes elméleti munkák azt hangsúlyozzák, hogy a dinamikus képesség a fenntartható versenyképességi előny forrása (Teece et al., 1997), míg más munkák ezzel ellentétben azt, hogy az azok alapjául szolgáló vállalati beidegződések egy idő után helyettesíthető és átültethetö legjobb gyakorlattá válnak (Eisenhardt - Martin, 2000). Cikkünkben alapul vesszük e két ellentétes nézetet és megpróbálunk fényt deríteni arra, hogy milyen feltételek során lehetséges dinamikus képesség révén versenyképességi előnyt kovácsolni.

A cikk keretében egy olyan magyar KKV esetét mutatjuk be, amely vállalkozott a szoftverfejlesztési folyamatának átfogó észszerüsítésére. A vállalkozásnál a munkatársak már több mint tíz éve foglalkoznak webes térképi alkalmazások fejlesztésével és több mint ötven projektben vettek részt. A vállalat a hagyományos vízeséses szoftverfejlesztési modellt követte, mert a fejlesztők tanulmányaik során ezt sajátították el és ennek alkalmazásában nagy tapasztalattal rendelkeztek. A cég ennek során sokszor szembesült azzal, hogy a tesztelés során nem teljesen azt a szoftvert és azt a szolgáltatást kapta, amit várt a fejlesztőktől. Adott funkció müködése sokszor nem volt megfelelö, bizonyos internetböngészőkben a szolgáltatás hibásan működött, illetve új funkciók és igények kifejlesztései jelentősen hátráltatták a projekt lezárását. A határidők be nem tartása, illetve a gyakori költségtúllépés a vevők számára elfogadhatatlanná vált, így a vállalatvezetésnek is lépnie kellett a belső folyamatok átalakítása és az erőforrások jobb menedzselése végett. A megvalósítást nehezítette, hogy a vállalatnál párhuzamosan több, akár 4-6 projekt is futott, amelyek részben közös erőforrásokat is használtak (pl. tesztelők, programozók), így az egyik projekt csúszása a másik futó projektre is hatással volt. Ezt a problémát már az irodalom a 90-es években feltárta (lásd: Tarek, 1993). Megoldást erre a problémára is egy rugalmasabb tervezési eljárástól reméltek, melyet a korábbi szakirodalmak is megerősítettek (lásd: pl. Nicholls et al., 2015).

A döntés értelmében a Scrum módszertant vezették be a célvállalat WMP (az angol Web Map Project rövidítése) nevü geoinformációs szoftverfejlesztési projektjének átfogó észszerüsítésére. A Scrum magán viseli a dinamikus képességek jegyeit, mivel radikálisan eltérő eljárást jelent a termékfejlesztésben eddig alkalmazottól, megváltoztatja az elemzett vállalat müködési logikáját és beidegződéseit, valamint alapvetően meghatározza annak piaci pozícióját. A vállalati információs rendszerből származó korábbi adatok és szakértői becslések, valamint szimulációs mód-

\footnotetext{
* Köszönetnyilvánítás:

Kosztyán Zsolt Tibor köszöni a Bolyai János kutatási posztdoktori ösztöndíj támogatását. Sebrek Szabolcs Szilárd köszöni a Nemzeti Kutatási, Fejlesztési és Innovációs Hivatalnak a PD16-121037 számú posztdoktori ösztöndíjat, amely nagyban hozzájárult a kutatás megvalósításához. Köszönetünket fejezzük ki a két bírálónak, valamint Chikán Attilának, Marco Giarratanának, Görög Mihálynak, Dirk-Jan Kamannak, Christian Stadlernek a cikk valamely változatával kapcsolatos véleményéért. Ezen túlmenően hálásak vagyunk az EIBA (2016. október, Budapest, Corvinus Business School), az MKE (2016. december, Budapest, Central European University) és a DRUID (2017. június, New York, Stern School of Business) konferenciák résztvevőinek az elhangzott hozzászólásokért.
} 
szerek segítségével összehasonlítottuk a jelenlegi és a kívánatos folyamatokat. Majd, mivel a vállalat be is vezette a Scrum módszertant, a bevezetés utáni időszakokat és a szimuláció által előrejelzett időtartamokat is összevetettük. A jelentős idő- és költségtúllépésre gyógyírt a szimulált Scrum szerinti folyamat jelentett, méghozzá a fö érintettek közötti hatékony összehangolás révén a közös tárhely és dokumentumszabályozás alkalmazásával. Ezt a szignifikanciavizsgálat is alátámasztotta. A vállalat a javaslatokat megfogadva az új folyamatterv által meghatározott logikai struktúrát követve alakította át a kiadás folyamatát, amely mind az átfutási idő, mind a költségek terén jelentős csökkentést tudott felmutatni, igazodva az előzetes szimulációk által becsült értékekhez.

Munkánk több ponton járul hozzá a dinamikus képesség elméletének alkalmazásához. A gazdag elméleti kidolgozottság ellenére (Peteraf et al., 2013; Teece et al., 1997; Winter, 2003; Helfat - Winter, 2011; Zollo - Winter, 2002), sajnos máig kevés a valós adatokon nyugvó gyakorlati tanulmány (ilyen kivétel Drnevich - Kriauciunas, 2011; Stadler et al., 2013; Yuan et al., 2016). Jelen cikkben e hiányosságon enyhítünk úgy, hogy egy problémákkal küszködő valós vállalat dinamikus képesség felfejlesztési szándékát tanulmányozzuk, az alkalmazott beidegződések megváltoztatásán keresztül a hatékonyabb müködés érdekében. Az elmélettel kapcsolatos gyakorlati munkák közül Zott (2003) szimulációs és Danneels (2011) részletes esettanulmánya emelendő ki. Cikkünk e két munkát ötvözi és egyszerre alkalmaz szimulációt és statisztikai elemzéseket, továbbá a vállalati átalakulási szándékot leíró részletes esettanulmányt. Ezáltal alátámasztjuk Teecet $(2007,2014)$ abban, hogy a kiemelkedő dinamikus képességgel bíró vállalatokat vállalkozói szemlélettel vezetik. Ezen túlmenően igazodunk Teece (2012) felhívásához, amely szerint a dinamikus képesség tetten érése nem csupán nagyminták alkalmazása által célravezető (például Helfat, 1997; Drnevich - Kriauciunas, 2011), hanem egy mélyreható vállalati eset megvalósításával is (például Danneels, 2011).

\section{A dinamikus képességek elmélete}

A fejezetben a dinamikus képesség fogalmi hátterét fogjuk lényegre törően megadni, továbbá használatának egyedi jellegzetességeit is feltárjuk. Végül a felső vezetés és a felhasználók szerepét is tisztázzuk e képesség vállalaton belüli felfejlesztési folyamatában.

\section{Az elmélet alapvetései}

A vállalati belső müködés átalakulását és annak teljesítményre gyakorolt hatását a dinamikus képességekkel kapcsolatos kutatások egyre összetettebben és egyre árnyaltabban festették le. Az egyik korai munkában Teece és Pisano (1994) úgy vélték, hogy a dinamikus képességek azon képességeket jelenítik meg, amelyek alkalmassá teszik a vállalatokat arra, hogy új termékeket és folyamatokat hozzanak létre a változó piaci feltételekre adandó válaszként. Teece és kollégái (1997) amellett érveltek, hogy a cégek stratégiai menedzsmentje hasznot húz ,a belső és külső szervezeti készségek, erőforrások és funkcionális szaktudás megfelelő alkalmazásával, egyesítésével, újra rendezésével" (515. oldal). Amennyiben a piacra jutási idő és a piaci időzítés kulcsfontosságú a szervezet számára, a dinamikus képességek által kiváltott újító jellegű szervezeti válaszok szerepe felértékelődik (Teece et al., 1997).

Az elmélet kulcsvonása a müködési (operational) és a dinamikus képességek közötti különbségtétel. A müködési, azaz nem dinamikus képességeket arra alakították ki, hogy megőrizzék a belső folyamatok állandóságát, amely változatlan viszonyok mellett hozzájárul a kiegyensúlyozott vállalati teljesítményhez (Helfat - Winter, 2011). Ezzel szemben a dinamikus képességek alkalmazása különböző, hatékonyabb eljárásokat tesz lehetővé, támogatva a jelenlegi vagy új termékeket és szolgáltatásokat, ugyanazon vagy új fogyasztói kör számára (Helfat - Winter, 2011). A dinamikus képességek birtoklása iránymutató a szervezet jövőbeli piaci sikerességét tekintve (Winter, 2003; HelfatWinter, 2011; Yuan et al., 2016). Jellemzően felvásárlások, szövetségkötés, licencátadás vagy új termék fejlesztése fémjelzi az elmélet hatókörét, eddigi alkalmazási eseteit (Iansiti - Clark, 1994; Helfat, 1997; Eisenhardt - Martin, 2000; Helfat et al., 2007; Helfat - Winter, 2011; Yuan et al., 2016). Zollo és Winter (2002) rámutatott arra, hogy e szervezeti képességek tanulhatók és szilárd alapot biztosítanak ahhoz, hogy a szervezet elöállítsa vagy megváltoztassa működési rutinjait a hatékonyság növelése érdekében.

Eisenhardt és Martin (2000) rámutatott a kapcsolatra, amely a dinamikus képességek és az erőforrások között állnak fenn. Vélekedésük szerint előbbiek arra irányulnak, hogy javítsák bizonyos tevékenységek és szervezeti folyamatok kivitelezését azáltal, hogy erőforrásokat egyesítenek, újra rendeznek vagy felszabadítanak. Egy szoftverfejlesztő vállalat esetén kulcserőforrás a szoftverfejlesztő mérnökök száma, rendelkezésre állásuk, illetve a vevő, mint a fejlesztési folyamat résztvevője. Amenynyiben a dinamikus képességek vállalati alkalmazása a szoftverkiadási időszakot lerövidíti és olcsóbbá teszi, úgy a szóban forgó vállalat értékes mérnöki erőforrást szabadít fel, amely akár új piaci rések meghódítását vonhatja maga után. A szoftverfejlesztési módszertant átszabó dinamikus képességek lehetőséget teremthetnek új tevékenységek bevonására és bizonyos korábbiak elhagyására, azaz a tevékenységek újra rendezésére. Ha e folyamat eredményeképpen a vevőket hatékonyabban be tudják vonni a fejlesztési folyamatba, akkor a mérnöki-fejlesztöi szaktudás és a vevői kontroll egyszerre van jelen a fejlesztési folyamat során, azaz erőforrást egyesítenek.

\section{Teece hármas felosztása}

Elméleti és elemzési szempontból egyaránt jelentős Teece-nek (2007) a dinamikus képességeket érintő hármas felosztása: érzékelés, megragadás és átalakítás. Az érzékelés az üzleti lehetőségek (és/vagy veszélyek) észlelését és kialakítását foglalja magában. Lehetőség lehet új fogyasztói igények azonosítása vagy exogén tudományos és technológiai fejlesztések vállalati gyakorlatba való ültetése (Teece, 2007). Az érzékelés során Teece fontos szerepet tulajdonít a vállalati vezetőknek, a felhasználóknak és a nyílt innovációnak egyaránt. A lehetőségek észlelése után, 
a vállalatnak meg kell azokat ragadni új folyamatok, tevékenységek, és termékek/szolgáltatások formájában (Teece, 2007). Ez maga után von egyfajta befektetési fegyelmet, elkötelezettséget a $\mathrm{K}+\mathrm{F}$ felé, szaktudás megszerzését és új erőforrás-kombinációk megvalósítását (Katkalo et al., 2010). Tudásmenedzsment, tanulás és tervezés a folyamat része, amelyet a vezetés összehangolással és felügyelettel (Augier - Teece, 2009; Bohl, 2015; Enríquez-De-La-O, 2015; Teece, 2007), valamint együtt gondolkodási hajlandósággal (Helfat - Peteraf, 2015) segíthet.

Az átalakítás a harmadik általános dinamikus képességtípus a vállalat versenyképességre való alkalmasságát szolgálja és annak az alapos átalakulását vonhatja magával. A második, megragadás lépésben a felvázolt, kidolgozott folyamat bevezetése valósul meg, amely ezzel egyidejűleg eltávolítja a korábbi nem megfelelően működő operatív beidegződéseket és berögzült eljárásokat (Teece, 2007). A korábban említett tanulási elem itt is megjelenik. Az átalakulás célja a vállalati teljesítmény és mozgástér növelése (Teece, 2007).

\section{Dinamikus képesség a gyakorlatban}

Stadler és szerzőtársai (2013) a dinamikus képességek két fontos tulajdonságát mutatják be. Elsőként arra világítanak rá, hogy magának a dinamikus képességnek különböznie kell a képesség használatának a következményétől, hiszen a vállalati teljesítményjavulást csak így lehet objektív módon mérni. Cikkükben az olajkitermelés iparágát tanulmányozták, ahol e stratégiailag fontos fogalom mérése a mélységi képalkotási és az olajkútfúrási technológiák révén történt. Tanulmányukban rámutatnak arra, hogy az értékes erőforrásokra a vállalatok nem csak úgy rábukkannak, hanem az erőforráshoz való hozzájutás és azok további fejlesztése egy tudatos stratégiai folyamat keretében zajlik le. A cikkükben azt találják, hogy a dinamikus képesség birtoklása pozitívan befolyásolja mind az erőforráshoz való hozzájutás (olajlelöhely beazonosítása és próbafúrás), mind az erőforrás-fejlesztés (müködő olajkút létesítése) sikerét (Stadler et al., 2013). Végeredményben a szerzők arra szolgáltatnak kiváló példát, hogyan támogat egy müködő üzleti vállalkozást a szóban forgó képesség használata.

Ahogy fentebb említettük, az elméletre építő egyik fontos empirikus kutatásban a dinamikus képességeket a technológia fogalmával azonosítják (Stadler et al., 2013). Technológia lehet bármilyen módszertan, folyamat vagy rendszer, amely egyedi eszközök és eljárások révén egyfajta cél elérését szolgálja (Barnhart - Steinmetz, 1986). A technológia magában foglalhatja ipari vagy gyakorlati készségek tudományos tanulmányozását (Simpson Weiner, 1989), amelynek során az alkalmazott tudományok, mérnöki alkalmazások kitüntetett szerepet játszanak (Ehrilch, et al. 1980). Ezen túlmenően a technológia alapvető egysége az eljárás (technique), amely a Nelson és Winter (1982) által bevezetett rutinnal (magyarul beidegződés) rokon fogalom (Durlauf Blume, 2008). Az eljárás alapvetően egy utasításhalmaz a termék termelésére vagy a szolgáltatás előállítására vonatkozóan (Durlauf - Blume, 2008). A technológia lényegi vonása az előíró tudás biztosítása (Durlauf Blume, 2008).

A dinamikus képességek alapjául szolgáló vállalati beidegződések egy idő után helyettesíthetővé és átültethetővé válnak az egyes alkalmazási helyszínek és területek között (Eisenhardt - Martin, 2000). Ez azt jelenti, hogy a kidolgozott és a gyakorlatban hatásosnak bizonyuló képességek átvihetők a kifejlesztő szervezetből akár egy másik iparágba is. A dinamikus képességek további jellegzetességei, hogy önmagukban nem feltétlenül szolgáltatják a versenyképességet, valamint több fontos sajátos részletben eltérhetnek az alkalmazó szervezetnél (Eisenhardt - Martin, 2000). Tételezzük fel, hogy egy informatikával foglalkozó cég vagy közösség kidolgoz egy új szoftverfejlesztési módszert, amely valahol beválik, és ezután maga a módszertan átültethető egy másik felhasználó (szoftverfejlesztő) szervezetbe. Önmagában a módszertan bevezetése azonban nem okvetlen hozza maga után a remélt teljesítményjavulást. Számos tényező, úgymint a felső vezetés bevezetés melletti elkötelezettsége, a szoftvermérnökök nyitottsága, a felhasználók segítőkészsége, a cég vezetési-szervezési rendszere, mind-mind elősegíthetik vagy akadályozhatják a remélt haszon realizálását (Aranyossy - Blaskovics - Horváth, 2015).

A cikk gyakorlati fejezetében arra keressük a választ, hogy egy magyar KKV esetén hogyan változnak meg a termékfejlesztési folyamat müködési rutinjai, ebben a Teece-i hármas felosztásnak mi a szerepe, illetve valóban elérhetö-e jelentős teljesítményjavulás és stratégiai mozgástérbővülés?

\section{A szervezeti probléma és az akciókutatás szerepe}

Tanulmányunkban a vállalat egy saját fejlesztésű WMP nevü geoinformációs szoftverének negyedévi díjas térképszolgáltatás fejlesztését, azon belül a webes platformra fejlesztett szerver szoftverkiadási időszakait fogjuk vizsgálni. A WMP egy olyan szolgáltatás, mely szerverés ún. vékonykliens alkalmazásokból épül fel. A vékonykliens azt jelenti, hogy a felhasználók gépein semmit nem kell telepíteni, mert az internetböngészőből elérhető a teljes webes szolgáltatás. A felhasználó kéréseit a szerveralkalmazás szolgálja ki, mely a felhasználók számára láthatatlan.

A WMP-alkalmazás fejlesztése során mindig gondot okoz a kiadás előtti tesztelési időszak menedzselése. A kiadási folyamat fejlesztése előtt a vállalat a hagyományos vízeséses szoftverfejlesztési modellt követte, melynek lényege, hogy a fejlesztési ciklus lépéseit (elemzés, specifikáció, tervezés, kódolás, tesztelés, üzembe helyezés) az egyes tevékenységek egymás után követve valósulnak meg. Ennek köszönhetően nagyon sokszor szembesült azzal, hogy a tesztelés során sokszor nem teljesen azt a szoftvert és azt a szolgáltatást kapták, amit vártak a fejlesztőktől. Rendszeresen előfordult, hogy ilyenkor új funkció fejlesztésének igénye merült fel, vagy a meglévő funkció kisebb-nagyobb mértékü átalakítására volt szükség. A szolgáltatás a piacon elérhető, melyhez a tanulmányban 
szereplő vállalat negyedévente adott ki frissítéseket, ami elfogadott, bevett gyakorlat a webes térinformatikai alkalmazásoknál. A negyedéves frissítéseket két hetes kiadási időszakokban készítették el a frissítés előtti időszakban. Egy ilyen időszak első hete az elöre betervezett feladatok elvégzésével telik. A második héten történik a tesztelés és a hibajavítás. A tesztelésről a tesztelők jegyzőkönyvet készítenek. A tesztelési jegyzőkönyveket e-mailben küldik egymásnak tekintettel arra, hogy jellemzően távmunkában történik a foglalkoztatás. Legtöbbször mégis szükség van a tesztelés során tapasztaltak megbeszélésére. A menedzser dönti el, hogy az adott igény bekerüljön-e a hibajavítási folyamatba, vagy az új funkciót kifejlesszék-e az adott időszakban. A fentiek alapján láthatjuk, hogy nem lehet mindent elöre betervezni a fejlesztési folyamatba, mert mindig újabb és újabb igényeket támasztunk a folyamat során. Emiatt sajnos általában nem tudják tartani a határidőket, mivel a tesztelés során nem használnak megfelelö, rugalmas módszertant, emiatt felmerülnek újabb és újabb igények, valamint a javítások ütemezése sem megfelelö.

A WMP esetében a kiadási időszakokban rendszeresen előfordulnak az alábbi hibák, melyeket a tesztelők jeleznek a fejlesztőknek:

1. az adott funkció müködése nem megfelelö,

2. bizonyos internetböngészökben a szolgáltatás nem megfelelöen müködik,

3. a megfelelö használathoz új funkciók mihamarabbi fejlesztése szükséges.

A fentiek közül az első kettő nagyon gyakran előforduló probléma a folyamatban, melyek kezelésére a vállalat felkészült, elhárításukkal a tesztelési időszakban folyamatosan foglalkozik. Az új funkció kialakítása azonban teljesen felborítja a kiadási időszakot, és ha ezeket az új funkciókat is betervezik, akkor az eredeti ütemterv elhúzódik, a határidők betartása tarthatatlanná válik. Pedig várhatna a vállalat az új funkciók kifejlesztésével a következő időszakig, ha a funkciók implementálását priorizálná és ezek alapján döntene megvalósításukról (lásd: Kosztyán, 2013, 2015).

\section{Az alkalmazott munkamódszertan: akciókutatás}

A vállalatvezetés felismerte, hogy a lassú és nem hatékony szoftverfejlesztési folyamat saját erőből nem vagy nehezen lenne orvosolható, illetve a beavatkozás nem odázható el a versenyképességi előny csökkenése nélkül. Ezért a témában tapasztalt, szakértelemmel bíró egyetemi kutatók segítségét vették igénybe, amely az akciókutatást mint alkalmazandó módszertant vetítette elö.

Az akciókutatás használata elterjedt a menedzsmentirodalomban, például a beszerzés (Kamann - van Nieulande, 2010), a logisztika (Ross et al., 2006) vagy a gyártás területén (Gylling et al., 2015). Az akciókutatás fogalma Lewintől (1946) származik, aki az elméletfejlesztést a társadalmi rendszer megváltoztatásával kívánta úgy elérni, hogy abban a kutató tevékenyen vesz részt. Az akciókutatás jellegzetessége a probléma összetett termé- szete, az együttműködés létrejötte a kutatók és a szervezet tagjai között, és a részvételen alapuló megfigyelés a változás hatásainak a jobb megértése érdekében (Ross et al., 2006; Susman - Evered, 1978). Susman és Evered (1978) az akciókutatás öt szakaszát vázolja fel: a probléma azonosítása, a cselekvés megtervezése, a cselekvés végrehajtása, értékelés, illetve új ismeretek meghatározása és következtetések levonása (e két utóbbi szakaszra az öszszefoglaló fejezetben kerül sor). A kutatók és a vállalat közötti tevékeny kutatási együttmüködés 2014 augusztusában kezdődött, míg a második (negyedik) szakasz 2015 márciusában (2016 januárjában) végződött.

\section{Az adatok forrása}

A vizsgálat során összesen 35 korábbi fejlesztési időszak adatai álltak rendelkezésünkre, de a tevékenység-időtartamok becslésére a folyamatért felelős szakértő véleményét is megkérdeztük. Minden egyes szakértőnek nyilatkoznia kellett, hogy az adott tevékenység mennyi idő alatt valósulhat meg legkorábban (továbbiakban optimista időtartambecslés), illetve legvalószínübb esetben (továbbiakban legvalószínűbb időtartambecslés), valamint mennyi az az időtartam, melyet az adott tevékenység végrehajtása nem szokott meghaladni (továbbiakban pesszimista becslés). A szakértők becsléseit, valamint előzetes feltételezésünket, miszerint a folyamatok lefutása a projekt- és folyamatmenedzsmentben is a nagyon gyakran használt ún. béta eloszlást követi, a lefutott időszakok alapján statisztikai módszerekkel validáltuk. A vizsgálat során azt a megállapítást fogalmazhattuk meg, hogy a tevékenység-időtartamok inkább egyenletes eloszlást, mintsem béta eloszlást követtek. Ugyanakkor, az egyenletes eloszlás intervallumparamétereinek jó közelítését adták a szakértői becsélések optimista-pesszimista becslési párjai.

\section{A probléma azonosítása}

A vizsgált WMP-szoftver frissítését negyedévente végezték, és a frissítés előtt két hetes szoftverkiadási időszakokban dolgoztak. A korábbi folyamatban ezeket az időszakokat fejlesztési ciklusoknak hívták. Minden fejlesztési időszak megtervezésekor egy minta kiadási tervet használnak, amelyben rögzítik a szokásos feladatokat az adott kiadási időszakra. A munkaidő-beosztás napi 8 órát jelent. Az egyes órák között a jogszabályban meghatározott tíz perc szünet beleértendő az egyes tevékenységek átfutási idejébe. A minta kiadási terv esemény- és tevékenységlistáját az 1. táblázatban mutatjuk be. A táblázatban feltüntettük a tevékenységek sorszámát, magát a tevékenységet, a tevékenység tervezett átfutási idejét órában és a tevékenység tervezett költségét egy fiktív CT\$-ban adtuk meg, mivel a vállalat béradatai nem nyilvánosak. A CT\$-t a forintban meghatározott béradatok lineáris transzformációja, amely két költségelem egymáshoz viszonyított arányát nem változtatja. Ez a transzformáció nem befolyásolja az alkalmazott elemző módszerek által adott szignifikanciaeredményeket, ugyanakkor tiszteletben tartjuk a cég azon kérését, hogy a költségadatai ne jelenjenek meg, különö- 
sen ebben az időszakban, amikor az egyik fontos probléma épp az informatikushiány. A bérköltségek kiadása akár hátrányosan is érinthetné a vállalatot.

Az 1. táblázatban a párhuzamos tevékenységeket sötétebb színnel jelöltük. Az egyes tevékenységeket órában határoztuk meg. A folyamatmodellben az órabér részét képezi a munkáltatót terhelö összes bérköltség.

1. táblázat

A WMP-projekt kiadási időszakainak korábbi mintaterve ( $A=$ tevékenységek, $E=$ események)

\begin{tabular}{|c|c|c|c|}
\hline $\begin{array}{l}\text { Sor- } \\
\text { szám }\end{array}$ & Tevékenység & $\begin{array}{c}\text { Tevé- } \\
\text { kenység } \\
\text { tervezett } \\
\text { átfutási } \\
\text { ideje } \\
\text { (óra) }\end{array}$ & $\begin{array}{c}\text { Tevé- } \\
\text { kenység } \\
\text { tervezett } \\
\text { költsége } \\
\text { (CT\$) }\end{array}$ \\
\hline E1 & Fejlesztési ciklus elkezdődött & 0 & 0,00 \\
\hline A1 & Tervezés: kezdeti funkciók & 1,5 & 50,38 \\
\hline E2 & Kezdeti funkciók meghatározva & 0 & 0,00 \\
\hline A2 & $\begin{array}{l}\text { Tervezés: funkciók frissítése és } \\
\text { priorizálása }\end{array}$ & 0,25 & 3,97 \\
\hline E3 & Funkciók frissítve és priorizálva & 0 & 0,00 \\
\hline A3 & $\begin{array}{l}\text { Tervezett feladatok rögzítése és } \\
\text { feladatkiosztás }\end{array}$ & 0,25 & 3,97 \\
\hline E4 & $\begin{array}{l}\text { Tervezett feladatok rögzítve és } \\
\text { kiosztva }\end{array}$ & 0 & 0,00 \\
\hline A4 & Fejlesztői terv elkészítése & 2,5 & 64,86 \\
\hline E5 & Fejlesztői terv elkészült & 0 & 0,00 \\
\hline A5 & 1. feladatcsoport elvégzése & 26 & 310,49 \\
\hline E6 & 1. feladatcsoport elvégezve & 0 & 0,00 \\
\hline A6 & $\begin{array}{l}\text { 1. feladatcsoport fejlesztői teszte- } \\
\text { lése }\end{array}$ & 13 & 155,25 \\
\hline A7 & 2. feladatcsoport elvégzése & 26 & 364,03 \\
\hline E7 & 2. feladatcsoport elvégezve & 0 & 0,00 \\
\hline A8 & $\begin{array}{l}\text { 2. feladatcsoport fejlesztői tesz- } \\
\text { telése }\end{array}$ & 13 & 182,01 \\
\hline E8 & Fejlesztői tesztelés hibamentes & 0 & 0,00 \\
\hline A9 & $\begin{array}{l}\text { Felhasználói tesztelés I., hibák be- } \\
\text { jelentése }\end{array}$ & 16 & 298,56 \\
\hline E9 & $\begin{array}{l}\text { Felhasználói tesztelés I. elvégez- } \\
\text { ve, hibák bejelentve }\end{array}$ & 0 & 0,00 \\
\hline A10 & Hibák javítása I. & 8 & 207,54 \\
\hline E10 & Hibák javítva I. & 0 & 0,00 \\
\hline A11 & Fejlesztői tesztelés és javítás II. & 4 & 103,77 \\
\hline E11 & Fejlesztöi tesztelés II. hibamentes & 0 & 0,00 \\
\hline A12 & $\begin{array}{l}\text { Felhasználói végtesztelés, beje- } \\
\text { lentett hibák csoportosítása, pri- } \\
\text { orizálása }\end{array}$ & 4 & 74,64 \\
\hline E12 & $\begin{array}{l}\text { Felhasználói végtesztelés elvé- } \\
\text { gezve, adott fejlesztési ciklusban } \\
\text { nincs több javítandó hiba }\end{array}$ & 0 & 0,00 \\
\hline A13 & Aktuális verzió kiadása & 0,5 & 7,00 \\
\hline E13 & Aktuális verzió kiadva & 0 & 0,00 \\
\hline A14 & Záró megbeszélés & 4 & 312,75 \\
\hline \multirow[t]{3}{*}{ E14 } & Záró megbeszélés dokumentálása & 0 & 0,00 \\
\hline & $\begin{array}{l}\text { Párhuzamos tevékenység miatt le- } \\
\text { vonandó (óra) }\end{array}$ & -39 & \\
\hline & Összesen & 80 & 2139,22 \\
\hline
\end{tabular}

Az 1. táblázatban látható, hogy az előzőekben ismertetett folyamat tervezett átfutási ideje 80 óra, a költsége pedig 2139,22 CT\$. Az általunk vizsgált 35 időszak mindegyikében jelentősen eltértek a tervtől. Számokban kifejezve az eltérést, a 35 vizsgált időszakra számított átlagos költség: 3838,55 CT\$, az átfutási idő pedig 147,5 óra volt, ami 79,44\%-os, valamint $84,44 \%$-os átlagos túlköltekezést, illetve átlagos csúszást jelentett, ami egyébként megfelel a nemzetközi gyakorlatnak (lásd Chaos Reports (Standish Group, 2016) jelentését). Mint ahogy ezt korábban már említettük, a fö problémát az jelentette, hogy a tesztelés során nemcsak hibákat javítanak, hanem új funkciók kifejlesztését is megengedik, így a projektet csak késéssel lehet lezárni. Mivel ezt az állapotot nem szerették volna fenntartani, ezért megoldást kerestek a folyamat javítására.

Következésképpen az akciókutatás céljával összhangban a kutatók beazonosították a pontos szervezeti problémát (a szoftverfejlesztés kiadási folyamatában jelentős idő- és költségtúllépés, főképp az új funkciók kifejlesztéséhez kapcsolódóan), amelynek kiküszöbölésére alább javaslatot tettek. Érdemes megjegyezni, hogy ez a szakasz a Teece-i (2007) hármas felosztásban az érzékelésnek felel meg, minthogy a nyílt innovációs együttmüködés révén a szervezeti fó tevékenységgel kapcsolatos veszélyekre és problémákra világít rá. A vállalatvezetés támogatólag lépett fel, illetve bízott abban, hogy az esetleges folyamatészszerüsítés új üzleti lehetőségek kiaknázását rejti magában.

\section{A Scrum bemutatása}

A Scrum elsősorban szoftvertermékek fejlesztéséhez kialakított keretrendszer (Dingsøyr et al., 2012), amit az utóbbi években már Magyarországon is egyre gyakrabban alkalmaznak. A módszertan lényege az inkrementális folyamatszabályozási megközelítés, amely a vevővel való együttmüködésre nagymértékben épít (lásd részletesen Schwaber - Beedle, 2002). A Scrum módszertan szerint a fejlesztési ciklusok helyett/mellett inkább ún. sprinteket használnak, amely általában egy rövidebb, 2-5 hetes idöszakot ölel fel.

A témában jártas, tapasztalattal rendelkező egyetemi kutatók a Scrum szoftverfejlesztési módszertan bevezetését javasolták az alkalmazott vízeséses kiváltására. Annak ellenére, hogy a Scrum módszertan fontos jellemzője a vevők bevonása a fejlesztésbe, új funkciók csak a következő sprintekre ütemezhetök.

\section{A Scrum mint dinamikus képesség}

Ezen a ponton érdemes számot adni arról, hogy a Scrum milyen jellemzőkben viseli magán a dinamikus képességek előzőekben felvázolt jegyeit. Elsőként, eltérő eljárást jelent a jelenleg a termékfejlesztésben eddig alkalmazottól, és a szoftverfejlesztési folyamat észszerüsítése révén alapvetően meg fogja határozni a célszervezet megélhetését. Másodszor, gyökeresen megváltoztatja a vállalat müködési logikáját, operatív rutinjait és müködési képességeit. A Scrum alkalmazásának az is az előnye, hogy megszünteti azon tevékenységeket, amelyek az üzleti érték maximali- 
zálásához nem járulnak hozzá (Wysocki, 2012). Harmadsorban, a termelési folyamat rendszerében fog változást hozni, mivel a vállalat a felszabaduló kapacitás nyomán több vevőt tud kiszolgálni a jelenlegi termékek kapcsán, vagy elkezdhet egy portfóliónövelő stratégiát követni (Giarratana, 2004; Giarratana - Fosfuri, 2007). Ez iparágon belüli diverzifikációt jelent, amely képessé teszi a vállalatot arra, hogy a termelési tényezőket racionálisan tudja kihasználni (Li - Greenwood, 2004), nagyobb védelmet élvezzen az új belépőkkel szemben a magasabb belépési korlátok révén (Lancaster, 1990), jobb túlélési esélyekkel rendelkezzen (Giarratana - Fosfuri, 2007), jobban bebiztosítsa magát instabil környezetben (Dobrev et al., 2002), és a pozitív kínálati hatásokból részesüljön (Siggelkow, 2003). A határozott növekedési szándék a magyar KKV-k számára fontos célkitűzés (Szabó, 2012). vonatkozóan. Ilyen jellegzetes rutin, hogy egy ún. sprinten belül nem engedélyezi új felhasználói igények bevonását.

\section{Az átalakítások tesztelése}

Mind a jelenlegi folyamatokat, mind a tervezett átalakítás után kapott folyamatok tevékenységeit az ARIS eEPC (extended Event-driven Process Chain) diagramjának segítségével ábrázoltuk. Itt a tevékenységek és azok eredményei, illetve új tevékenységek kiváltó okaiként tekinthető események egy úgynevezett páros gráfban ábrázolhatók.

A tevékenységeket/eseményeket, amennyiben párhuzamosan lesznek végrehajtva, ún. ÉS operátor jelöli, míg a döntési (ún. kizáró vagy) operátort egy + jelöli. Itt az ágak egymást kizárják. Vagy az egyik, vagy a másik ág valósul meg, melyekhez az eddigi lefutások alapján rela-

Az elméletben lefektetett dinamikus képesség tulajdonságok és a várt gyakorlati hatások a WMP-projektben

\begin{tabular}{|c|c|c|}
\hline $\begin{array}{l}\text { Az elméletből eredeztethető dinamikus } \\
\text { képesség tulajdonságok }\end{array}$ & Szakirodalmi forrás & $\begin{array}{c}\text { Várt hatás a Scrum bevezetése révén a } \\
\text { vizsgált szervezeten }\end{array}$ \\
\hline Hatékonyabb termékfejlesztés & Eisenhardt - Martin, 2000 & $\begin{array}{c}\text { Gyorsabb és kevésbé költségesebb } \\
\text { szoftverfejlesztési folyamat }\end{array}$ \\
\hline $\begin{array}{c}\text { Döntő a talpon maradást illetően a status } \\
\text { quo megváltoztatása által }\end{array}$ & Winter, 2003; Helfat - Winter, 2011 & $\begin{array}{l}\text { Hatékonyabb müködés pozitívan } \\
\text { befolyásolja a megélhetést }\end{array}$ \\
\hline Átszabja az operatív rutinokat & Zollo - Winter, 2002 & $\begin{array}{l}\text { A kiadási folyamatban új tevékenységek } \\
\text { jelenhetnek meg, régieket hagyhatnak el }\end{array}$ \\
\hline Jobb müködési képesség & $\begin{array}{l}\text { Winter, 2003; Stadler et al., 2013; Yuan et } \\
\text { al., 2016; Teece, } 2007\end{array}$ & $\begin{array}{c}\text { Gyorsabb és kevésbé költségesebb } \\
\text { szoftverfejlesztési folyamat } \\
\text { Több projekt megvalósítása egy adott } \\
\text { időszak alatt }\end{array}$ \\
\hline Alaposabb vásárlói igénykielégítés & Helfat - Winter, 2011 & $\begin{array}{c}\text { Kiadási folyamatban keletkező csúszások } \\
\text { kiküszöbölése }\end{array}$ \\
\hline $\begin{array}{c}\text { Eredményesebb stratégiai tervezöi } \\
\text { képesség }\end{array}$ & Helfat - Winter, 2011 & Termelési kapacitás kiegyenlítése \\
\hline $\begin{array}{l}\text { Új erőforráshoz való hozzájutás és annak a } \\
\text { továbbfejlesztése }\end{array}$ & Stadler et al., 2013 & $\begin{array}{l}\text { A szoftver demo változata, majd a } \\
\text { késztermék a kiadási folyamat végén }\end{array}$ \\
\hline
\end{tabular}

Negyedszer, lehetővé teszi a felhasználó számára igényeik jobb, késések nélküli kielégítését. Ötödször, a Scrum lényegesen javítja a stratégiai tervezési képességet a termelési kapacitás kiegyenlítése által. Ezen felül a Scrum különbözik a használatának következményeitöl, amely az elmélet egyik fontos kritériuma, és hozzásegíti az alkalmazó szervezetet új erőforrásokhoz való hozzájutáshoz és azok továbbfejlesztéséhez (Stadler et al., 2013). A fenti elméleti és gyakorlati összefüggéseket a 2. táblázatban foglaljuk össze.

A Scrum az inkrementális modellek családjának tagja, amely az agilis fejlesztési módszertanok körébe tartozik (Schwaber - Beedle, 2002), tehát az elméleti részben kifejtettekkel összhangban technológiát jelent. Az agilis projektmenedzsmentet főképpen szoftverfejlesztési projektekre alkalmazzák (Dingsøyr et al., 2012), de új termék kifejlesztésére is kiterjeszthető (Fekri - Aliahmadi - Fathian, 2009). A Scrum ezért magában foglal gyakorlati készségeket a mérnöki informatika területéről. A Scrum utasításokat tartalmaz a szoftver végtermék előállítására tív gyakoriságokat, vagy szakértői becsléseken alapuló (szubjektív) valószínüségeket lehet rendelni (lásd pl. 3. táblázat). Ezeket a valószínüségeket/relatív gyakoriságokat az események bekövetkezéseként értelmezzük és a 3-5. táblázatokban az eseményekhez rendeljük. Időt, költségeket csak a tevékenységekhez lehet rendelni. Ezek meghatározásánál egyrészt figyelembe vettük a korábbi időszakok adatait, másrészt a területekért felelős szakértőket kértünk fel, hogy segítsenek az idő- és költségadatok becslésében. A szakértői becsléseket a meglévő adatok felhasználásával validáltuk (lásd: előző fejezetet), majd ezeket felhasználva lehetséges eseteket szimuláltunk. Az idő- és költségadatokat összehasonlítva szignifikanciavizsgálatokat végeztünk, hogy a Scrum módszertan, valamint a közös dokumentumkezelés bevezetése szignifikánsan csökkenti-e a költség- és időadatokat. A vizsgálatok segítségével javaslatot tettünk az átalakításra, majd ennek alkalmazását további 17 időszakon tesztelve megvizsgáltuk, hogy a tervezett idő- és költségadatokat mennyire sikerült betartani. 


\section{Az eredmények értékelése}

Az átalakításokat a következőképpen értékeltük: (1) Hogyan változott, hogyan egyszerüsödött a folyamatok struktúrája? Hogyan változott/csökkent az átalakítások nyomán a folyamatok (várható) (2) idő-, illetve (3) költségigénye? Minden egyes esetben a Monte Carlo szimuláció alkalmazásának követelményein túlmutatva 10000-10000 időszakot szimuláltunk. Az egyes lehetséges értékeket a szakértői becslések validálása után a (szakértői) optimista és pesszimista becslések intervallumán felvett egyenletes eloszlást követve szimuláltuk.

\section{A cselekvés megtervezése: a logikai tervek összehasonlítása}

A 3. táblázat a jelenlegi folyamatot tartalmazza, melyben a szakértői becslések közül a legvalószínübb értékek szerepelnek, hiszen a szakértők az ettől rövidebb idő- és

Az eredeti folyamat logikai terve

\begin{tabular}{|c|c|c|c|c|}
\hline $\begin{array}{c}\text { Sor- } \\
\text { szám }\end{array}$ & Tevékenység & \begin{tabular}{|c|} 
Tevékenység \\
elvégzéséhez \\
szükséges \\
becsült idő (óra) \\
\end{tabular} & \begin{tabular}{|c|}
$\begin{array}{c}\text { Tevékenység } \\
\text { becsült } \\
\text { költsége (CT\$) }\end{array}$ \\
\end{tabular} & $\begin{array}{l}\text { Bekövet- } \\
\text { kezés } \\
\text { valószínú- } \\
\text { sége }\end{array}$ \\
\hline E1 & Fejlesztési ciklus el kezdődött & legvalószínúbb & \begin{tabular}{|r|} 
legvalószínübb \\
0,00
\end{tabular} & \begin{tabular}{|l|} 
sege \\
1
\end{tabular} \\
\hline $\mathrm{A} 1$ & Tervezés: kezdeti funkciók & 1,5 & 50,38 & \\
\hline E2 & Kezdeti funkciók meghatározva & 0 & 0,00 & 1 \\
\hline A2 & Tervezés megbeszélés & 1,5 & 89,29 & \\
\hline E3 & Tervezés megbeszélve & 0 & 0,00 & 1 \\
\hline A3 & Tervezés: funkciók frissítése és priorizálása & 0,25 & 3,97 & \\
\hline E4 & Funkciók frissítve és priorizálva & 0 & 0,00 & 1 \\
\hline A4 & Tervezett fela datok rögzítése és fela datkiosztás & 0,25 & 3,97 & \\
\hline E5 & Tervezett fela datok rögzítve és kiosztva & 0 & 0,00 & 1 \\
\hline A5 & Fejlesztői terv el készítése & 2 & 51,89 & \\
\hline E6 & Fejlesztői terv elkészül & 0 & 0,00 & 1 \\
\hline A6 & 1. feladatcsoport elvégzése & 30 & 358,26 & \\
\hline E7 & 1. feladatcsoport elvégezve & 0 & 0,00 & 1 \\
\hline A7 & 1. feladatcsoport fejlesztői tesztelése & 15 & 179,13 & \\
\hline A8 & 2. feladatcsoport elvégzése & 30 & 420,03 & \\
\hline E8 & 2. feladatcsoport elvégezve & 0 & 0,00 & 1 \\
\hline A9 & 2. feladatcsoport fejlesztői tesztelése & 15 & 210,02 & \\
\hline E9 & Feljesztői tesztelés hibamentes & 0 & 0,00 & 1 \\
\hline A10 & Fel használói tesztelés I., hibák és új funckió bejelentése & 18 & 335,88 & \\
\hline E10 & Fel használói tesztelés I.elvégezve,hibák és új funkc. bejelentve & 0 & 0,00 & 1 \\
\hline A11 & Tesztelés eredményének megbeszélése & 3,5 & 156,11 & \\
\hline E11 & Tesztelés eredménye megbeszélve & 0 & 0,00 & 1 \\
\hline A12 & Új funkció fejlesztői terv el készítése & 1 & 25,94 & \\
\hline E12 & Új funkció fejlesztői terv elkészül & 0 & 0,00 & 0,99 \\
\hline A13 & új funkció el készítése & 12 & 311,32 & \\
\hline E13 & Új funkció el készítve & 0 & 0,00 & 0,99 \\
\hline A14 & Hibák javítása I. & 14 & 363,20 & \\
\hline E14 & Hibák javítva I. & 0 & 0,00 & 1 \\
\hline A15 & Fejlesztői tesztelés és javítás II. & 8 & 207,54 & \\
\hline E15 & Feljesztői tesztelés II. hibamentes & 0 & 0,00 & 1 \\
\hline A16 & Fel használói tesztelés II., hibák bejelentése & 11 & 205,26 & \\
\hline E16 & Felhasználói tesztelés II. elvégezve, hibák bejelentve & 0 & 0,00 & 1 \\
\hline A17 & Hibák javítása II. & 7 & 181,60 & \\
\hline E17 & Hibák javítva II. & 0 & 0,00 & 1 \\
\hline A18 & Fejlesztői tesztelés és javítás III. & 4 & 103,77 & \\
\hline E18 & Feljesztői tesztelés III. hibamentes & 0 & 0,00 & 1 \\
\hline A19 & Fel használói végtesztelés, bejelentett hibák csop, priorizálása & 14 & 261,24 & \\
\hline E19 & $\begin{array}{l}\text { Felhasználói végtesztelés elvégezve, a dott fejlesztési } \\
\text { ciklusban nincs több javítandó hiba }\end{array}$ & 0 & 0,00 & 1 \\
\hline A20 & Aktuális verzió kiadása & 0,5 & 7,00 & \\
\hline E20 & Aktuális verzió kiadva & 0 & 0,00 & 1 \\
\hline A21 & Záró megbeszélés & 4 & 312,75 & \\
\hline E21 & Záró megbeszélés dokumentálva, időszzak lezárva & 0 & 0,00 & 1 \\
\hline
\end{tabular}


költségbeli eltérést 10\%-ban (optimista becslés), míg a csúszásokat, költségtúllépéseket 30\%-ban (pesszimista becslés) határozták meg. Mivel a megfigyelések száma csekély, ezért a megbízhatóbb $\chi^{2}$-próba helyett csak Kolmogorov-Smirnov próbával tudtuk igazolni, hogy az idöés költségadatok megoszlása egyenletes eloszlást követ, másrészt, hogy az optimista-pesszimista becslések jó közelítéssel megadják az egyenletes eloszlás intervallumának széleit.

A folyamatok feltárása egyértelmüen megmutatta, hogy a leghosszabb és legköltségesebb folyamatok az eredeti feladat elkészítése mellett a hibák javításából és az új funkciók implementálásából adódik. A 21 tevékenységből több is ismétlődik (pl. hibák javítása), és bár ezek maximális száma limitált, mégis jelentősen, majdnem kétszeresére növelik a kiadási folyamat hoszszát.

A Scrum módszertanra való áttérés jelentősen szükítené az előforduló tevékenységek számát (4. táblázat). Limitálja az új feladatok, funkciók beütemezésének számát, miközben a folyamatok fejlesztésébe bevonja magát a felhasználót is.

\section{A Scrum módszertant követő tervezett folyamat}

\begin{tabular}{|c|c|c|c|c|c|}
\hline \multirow[t]{2}{*}{$\begin{array}{l}\text { Sor- } \\
\text { szám }\end{array}$} & \multirow[t]{2}{*}{ Tevékenység } & 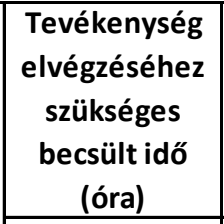 & $\begin{array}{c}\begin{array}{c}\text { Tevékenység } \\
\text { becsült } \\
\text { költsége (CT\$) }\end{array} \\
\end{array}$ & \multirow[t]{2}{*}{$\begin{array}{c}\text { Bekövet- } \\
\text { kezés } \\
\text { valószí- } \\
\text { núsége }\end{array}$} & \\
\hline & & legvalószínűbb & legvalószínűbb & & \\
\hline E1 & Kiadási időszak elkezdődött & 0 & 0,00 & 1 & \\
\hline A1 & Sprint tervezés: kezdeti funkciók & 1,5 & 50,38 & & \\
\hline $\mathrm{E} 2$ & Kezdeti funkciók meghatározva & 0 & 0,00 & 1 & \\
\hline $\mathrm{A} 2$ & Tervezés megbeszélés & 1,5 & 89,29 & & \\
\hline E3 & Tervezés megbeszélve & 0 & 0,00 & 1 & \\
\hline A3 & Sprint tervezés: funkciók frissítése és priorizálása & 0,25 & 3,97 & & \\
\hline E4 & Funkciók frissítve és priorizálva & 0 & 0,00 & 1 & A5 \\
\hline A4 & Tervezett feladatok rögzítése és feladatkiosztás & 0,25 & 3,97 & & \\
\hline $\mathrm{E} 5$ & Tervezett feladatok rögzítve és kiosztva & 0 & 0,00 & 1 & \\
\hline A5 & Fejlesztői terv elkészítése & 2 & 51,89 & & \\
\hline E6 & Fejlesztői terv elkészült & 0 & 0,00 & 1 & A6 \\
\hline A6 & 1. feladatcsoport elvégzése & 30 & 358,26 & & (6) \\
\hline E7 & 1. feladatcsoport elvégezve & 0 & 0,00 & 1 & $T$ \\
\hline A7 & 1. feladatcsoport fejlesztői tesztelése & 15 & 179,13 & & \\
\hline A8 & 2. feladatcsoport elvégzése & 30 & 420,03 & & \\
\hline E8 & 2. feladatcsoport elvégezve & 0 & 0,00 & 1 & E9 \\
\hline A9 & 2. feladatcsoport fejlesztői tesztelése & 15 & 210,02 & & A10 \\
\hline E9 & Feljesztői tesztelés hibamentes & 0 & 0,00 & 1 & \\
\hline A10 & $\begin{array}{l}\text { Felhasználói tesztelés I., új funkció felvétele a } \\
\text { következő sprintbe }\end{array}$ & 18 & 335,88 & & A11 \\
\hline E10 & $\begin{array}{l}\text { Felhasználói tesztelés I. elvégezve, új funckió } \\
\text { felvéve a következő sprintbe }\end{array}$ & 0 & 0,00 & 1 & \\
\hline A11 & Tesztelés eredményének megbeszélése & 3,5 & 156,11 & & A12. \\
\hline E11 & Tesztelés eredménye megbeszélve & 0 & 0,00 & 1 & E12. \\
\hline A12 & Hibák javítása I. & 14 & 363,20 & & \\
\hline E12 & Hibák javítva I. & 0 & 0,00 & 1 & \\
\hline A13 & Fejlesztői tesztelés és javítás II. & 8 & 207,54 & & E13 \\
\hline E13 & Feljesztői tesztelés II. hibamentes & 0 & 0,00 & 1 & \\
\hline A14 & $\begin{array}{l}\text { Felhasználói végtesztelés, bejelentett hibák } \\
\text { csoportosítása, priorizálása }\end{array}$ & 14 & 261,24 & & \\
\hline E14 & $\begin{array}{l}\text { Felhasználói végtesztelés elvégezve, adott } \\
\text { fejlesztési ciklusban nincs több javítandó hiba }\end{array}$ & 0 & 0,00 & 1 & A15 \\
\hline A15 & Aktuális verzió kiadása & 0,5 & 7,00 & & E15 \\
\hline E15 & Aktuális verzió kiadva & 0 & 0,00 & 1 & A16 \\
\hline A16 & Záró megbeszélés & 4 & 312,75 & & ह16 \\
\hline E16 & Záró megbeszélés dokumentálva, időszak lezárva & 0 & 0,00 & 1 & \\
\hline
\end{tabular}


A folyamatban részt vevő szoftvermérnökök fontosnak tartották megjegyezni, hogy a kiadási időszakban a tervezéskor és a teszteléskor is gyakran nehézkes volt egyes dokumentumok kezelése, a verziókövetés és a dokumentumok megosztása. A dokumentumokat a fejlesztési folyamat elött e-mailben küldték meg egymásnak. Ugyan már korábban is volt közös tárhelyük, azonban onnan nem tudták direktben megnyitni a dokumentumokat, hanem elöbb le kellett tölteniük a helyi gépre. Mivel nem volt egységes, webalapú dokumentumkezelés, így a dokumentumok egyeztetése, keresése nem volt gördülékeny. A kiadási időszak tervezése úgy történt, hogy a projektvezető megírta a kiadási időszak tervét, majd megküldte az érintetteknek. Ezután egy megbeszélés során egyeztették a tervet és a módosításokat a projektvezető ismét átvezette a dokumentumon (lásd: 3. táblázat: A2 Tervezés megbeszélés + A3 Tervezés: funkciók frissítése és priorizálása).

A dinamikus képességek elmélete (Teece et al., 1997) és az empirikus munkák (Stadler et al., 2013) azt mutatják, hogy a tevékenységek szoros összehangolása pozitívan befolyásolja a képességek alkalmazását. Az akciókutatás keretében, a szoftvermérnökök valódi szükségleteivel összhangban, a Google Docs dokumentumkezelö rendszert illesztették a kiadási folyamatba. A közös dokumentum- és tárhelyhasználat tovább egyszerüsíti a folyamatokat, melyet az 5. táblázat szemléltet.

Látható, hogy a tevékenységek számszerü csökkenését elsősorban a Scrum módszertan bevezetése eredményezte, de a közös dokumentum- és tárhelyhasználat is két tevékenység végrehajtásának kiiktatásával tovább rövidítette a folyamatlánc-diagramot.

\section{A költség- és időadatok összehasonlítása}

Már a szakértők által legvalószínübb időtartamokkal és költségigényekkel számolva is kitünik, hogy a legrövidebb/legkevésbé költséges folyamattervet a javasolt átalakítás adná (5. táblázat). Ugyanakkor pont az egyenletes eloszlás feltételezése miatt a legvalószínübb idő- és költ-

5. táblázat

A javasolt, a Scrum módszertant és a közös tárhely- és dokumentumkezelést is magába foglaló, folyamat

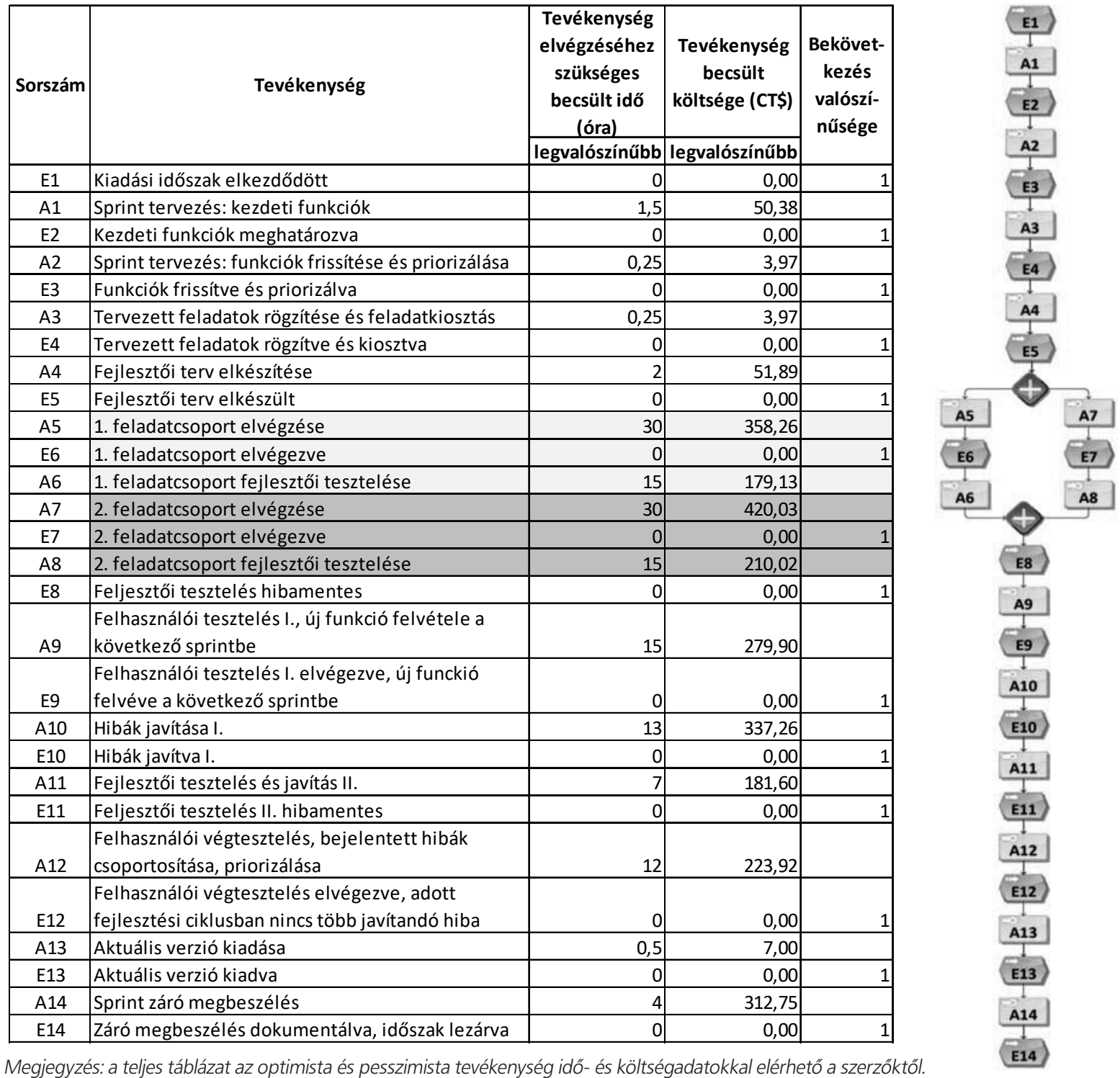


ségadatok nem jellemzik egyértelmüen a tevékenységek idő- és költségadatait, hiszen azok az optimista és peszszimista becslések által kifeszített intervallumon bármely értéket felvehetnek.

A szimulációt az előző fejezetben leírt módon végeztük el 10.000 időszakra. Csebisev egyenlőtlenségeken alapulva meghatároztuk a konfidencia intervallumokat, mely azt mutatta, hogy páronként összehasonlítva valamennyi folyamatterv szignifikánsan eltér egymástól. A Scrum módszertannal és Google Docs alapú közös tár- és dokumentumkezelési szabályozással vezetett kiadási időszakok teljes projektátfutási ideje 95\%-os megbízhatósági szint mellett (átfutási idők esetén normális eloszlást feltételezve) 111,2 órát kaptunk. A teljes várható átfutási idő 104,5 óra (szórás 4,1 óra). A teljes projekt költsége 95\%-os megbízhatósági szint mellett 2819,21 CT\$ (2669,16 CT\$ várható teljes költség, szórás: 91,22 CT\$).

A 6. táblázatban összefoglaltuk a szimuláció eredményeit. A táblázatban összehasonlítottuk a Scrum és a Scrum módszertannal Google Docs dokumentumszabályozással irányított folyamatok teljes átfutási idejét és teljes költségét.

6. táblázat

A terv, a valós, a Scrum, illetve a Scrum módszertan és a Google dokumentumszabályozás együttes használatából származó szimulációs adatok összefoglalása (95\%-os megbízhatósági szintre, Csebisev egyenlőtlenségek alapján számolt konfidencia intervallumok esetén)

\begin{tabular}{|l|c|c|}
\hline & $\begin{array}{c}\text { A teljes pro- } \\
\text { jektátfutási } \\
\text { idő (TPT) } \\
- \text { óra }\end{array}$ & $\begin{array}{c}\text { A teljes pro- } \\
\text { jektköltség } \\
\text { (TPC) - CT\$ }\end{array}$ \\
\hline Jelenlegi folyamat terv & 80 & 2139,22 \\
\hline $\begin{array}{l}\text { Jelenlegi folyamat } \\
\text { (szimuláció) }\end{array}$ & 160,4 & 4109,02 \\
\hline $\begin{array}{l}\text { Scrum szerinti folyamat } \\
\text { (szimuláció) }\end{array}$ & 123,9 & 3230,07 \\
\hline $\begin{array}{l}\text { Scrum + Közös tárhely és } \\
\text { dokumentumszabályozás } \\
\text { (szimuláció) }\end{array}$ & 111,2 & 2819,21 \\
\hline
\end{tabular}

A 6. táblázatból látható, hogy a legnagyobb átfutásiidö-csökkentést a Scrum módszertan bevezetése jelentette. Ugyanakkor a Scrum és a közös tárhely- és dokumentumszabályozás módszertan szerinti folyamattervet tekintve a teljes projektátfutási idő (95\%-os megbízhatósági szintet feltételezve) 123,9 óráról 111,2 órára csökkent, vagyis további 12,7 óra a csökkenés. Ez 8 órás munkanapokkal számolva majdnem két munkanap megtakarítást jelent. A jelenlegi folyamathoz képest ez a csökkenés már korántsem elhanyagolható: 49,2 óra.

A költségekben is jelentős változás következett be. Itt is a legnagyobb költségcsökkenés a Scrum módszertan bevezetését követi, ugyanakkor nem elhanyagolható a közös tárhely használata miatt jelentkező rövidebb folyamat okozta költségcsökkenés sem. Ebben az esetben 95\%-os megbízhatósági szint mellett 3230,07 CT\$-ról 2819,21 CT\$-ra csökkennek a költségek, vagyis a teljes projektköltség további 410,86 CT\$-ral csökkent. Ha az eredeti folyamattal vetjük össze az adatokat, akkor látható, hogy a javasolt komplex változtatásnak köszönhetően 1289,81 CT\$-ral csökkent a teljes költség, amely 31,39\%-os megtakarítást eredményez.

A kapott eredmények birtokában a kutatók a vállalatvezetésnek a Scrum és a közös tárhely- és dokumentumszabályozás alternatíva bevezetésére tettek javaslatot. A jövőbeni cselekvés megtervezése Teece (2007) megragadás tevékenységével egyenértékü az új folyamat lefektetése által. Az elmélettel összhangban, a kialakítandó szoftverfejlesztési folyamat a szervezet irányában új szaktudás megszerzését, elkötelezettséget és új erőforrás-kombinációk kialakítását (Katkalo et al., 2010), illetve tanulást (Teece, 2007) igényel. Ezen túlmenően, mint esetünkben is, a felső vezetés támogatását és együtt gondolkodási hajlandóságát is, amely a dinamikus képesség kialakítás lényeges eleme (Helfat - Peteraf, 2015). A szakirodalom szerint turbulens környezetben müködő projektalapú szervezetek esetén, mint amilyen a szóban forgó vállalat, a képességépítés és -fejlesztés lényeges tevékenység a versenyképesség megőrzésére (Lobo - Whyte, 2017).

\section{A cselekvés végrehajtása és a javasolt bevezetés nyomán kialakított új folyamat értékelése}

A dinamikus képesség nem vásárolható meg, hanem azt tudatosan ki kell építeni (Katkalo et al., 2010). A harmadik dinamikus képességfajta, az átalakítás, ezt a célt szolgálja az előző megragadás lépésben felvázolt folyamat (Scrum módszertan Google Docs dokumentum-szabályozással) bevezetésével. Az eredmények validálása az akciókutatás elengedhetetlen eleme (Kamann - van Nieulande, 2010).

A vállalat a javaslatokat megfogadva mind az 5. táblázat szerinti folyamatterv által meghatározott logikai struktúrát követve alakította át a kiadás folyamatát. Az első kettő kiadási folyamat még inkább a tanulási időszak jegyében telt el. A vevők bevonása a fejlesztési folyamatba önmagában csökkentette a sokszor félreértések miatt kialakult további funkcióbővítésekre irányuló kérések számát. Ugyanakkor meg kellett szokniuk, hogy ha mégis kérések merülnek fel, akkor azok a következő sprintidőszakban realizálódhatnak. A harmadik kiadási időszaktól kezdve további 17 - 2015 májusa és 2016 januárja közötti - kiadási időszakot vizsgálva azt tapasztaltuk, hogy a kockázatok felülbecslése ellenére sem sikerült olyan nagymértékben csökkenteni a folyamat idő- és költségadatait, mint azt a szimulációk előrejelezték. Ennek oka, hogy a szakértők az időtartamok, elsősorban a közös egyeztetések időtartamait kissé alulbecsülték. Ugyanakkor fontos eredmény, hogy a 17 kiadási időszak átlaga azt mutatta, hogy az átlag átfutási idő 41,7 órával, a költségek pedig 1158,82 CT\$-ral csökkentek, ami így is jelentős csökkentésnek mondható, és közel esik a szimuláció által becsült értékekhez. Külön érdekes és fontos eredmény, hogy a 17 vizsgált időszakból 5 alkalommal sikerült a terv szerinti 
80 órát és 2139,22 CT\$ kereteket betartani, ami szintén visszaigazolja a Chaos Reports (Standish Group, 2016) által végzett kutatások eredményét, amely mutatja, hogy az agilis szemléletet követő projektek jóval nagyobb mértékben tudják tartani a költség- és időkereteket, miközben a vevői igényeket is nagyobb százalékban képesek kielégíteni.

Winter (2003) szerint figyelmet kell fordítani a dinamikus képességekbe történő befektetés kapcsán a költség-haszon egyensúlyra. Ezért a kutatók költség-haszon elemzés révén gazdaságossági vizsgálatot végeztek, melynek során összevetették a költségeket és hasznokat. A 7. táblázatban összefoglaltuk a projekt tevékenységeit, az időtartamokat és a költségeket. A táblázatban a költség oszlopban tisztán a bérköltségeket tüntettük fel, mert anyagköltség nem merült fel.

7. táblázat

\section{A projekt részletes költségei}

\begin{tabular}{|l|c|c|}
\hline Tevékenység & Időtartam & Költség (CT\$) \\
\hline $\begin{array}{l}\text { Scrum és Google Docs } \\
\text { bevezetése projekt }\end{array}$ & $\mathbf{1 7 3 , 5}$ óra & $\mathbf{3 1 2 6 , 4}$ \\
\hline Kutatási tevékenység & $\mathbf{1 5 0}$ óra & $\mathbf{2 3 7 9}$ \\
\hline Szakirodalom feltárása & 86 óra & 1363,96 \\
\hline Empirikus vizsgálatok & 64 óra & 1015,04 \\
\hline Tervezés & $\mathbf{1 , 5}$ óra & $\mathbf{2 3 , 8}$ \\
\hline Előkészítés & 0,5 óra & 7,9 \\
\hline Tervezés & 1 óra & 15,9 \\
\hline Oktatás & $\mathbf{2 1}$ óra & $\mathbf{6 4 5 , 4}$ \\
\hline $\begin{array}{l}\text { Felkészülés, tananyag } \\
\text { elkészítése }\end{array}$ & 16 óra & 254,4 \\
\hline Scrum oktatása & 3 óra & 234,6 \\
\hline Google docs oktatása & 2 óra & 156,4 \\
\hline Zárás & $\mathbf{1}$ óra & $\mathbf{7 8 , 2}$ \\
\hline Záró megbeszélés & 1 óra & 78,2 \\
\hline
\end{tabular}

A hasznok összegzése úgy történt, hogy az eredeti folyamat költségét összevetettük a Scrum módszertannal és a Google Docs dokumentum-szabályozásra épülő javaslatban szereplő folyamat költségével. Az adatok azt mutatják, hogy a bevezetés költsége 3126,4 CT\$, valamint egyetlen sprint alatt 1158,82 CT\$ megtakarítást érünk el az új rendszer bevezetésével. Fentiekből az a következtetés vonható le, hogy a befektetés már a harmadik sprint alkalmával megtérül. A harmadik sprint során már 350,06 CT\$ megtakarítást jelent a projekt megvalósítása, míg minden további sprint során 1158,82 CT\$ megtakarítást ér el a vállalat. Az adatok továbbá azt mutatják, hogy egy sprint alatt 41,5 munkaóra megtakarítás érhető el a szoftverészszerüsítési törekvés által (160,4 és 118,9 órák különbsége), amely a 173,5 órára rúgó képességfejlesztés megtérülési idejét röviddel a negyedik sprint elkezdése utánra teszi. A 7. táblázatban feltárt tevékenységek is mutatják, hogy a tanulás szerves része a szervezeti folyamatok átalakításának az elmélet útmutatásával (Bohl, 2015; Enríquez-DeLa-O, 2015; Teece, 2007) egyetemben.

\section{Összefoglalás és következtetések}

Az üzleti tudományokban az egyre nagyobb jelentőségü dinamikus képesség elmélete szerint a müködési beidegződések megváltoztatása révén a vállalatok képessé válhatnak az erőforrások észszerübb kezelésére, a hatékonyabb működés biztosítására és a jövőbeli piaci sikeresség kivívására (Teece et al., 1997; Winter, 2003; Helfat - Winter, 2011; Stadler et al., 2013; Yuan et al., 2016). Cikkünkben elemeztük egy magyar KKV szoftverfejlesztési projektjének átalakítási lehetőségeit, amelyre a termékfejlesztési folyamat lassúsága és következetlensége miatt volt szükség. Részletes tanulmányunk az agilis családba tartozó Scrum szoftverfejlesztési módszer bevezetését követi nyomon.

A Scrum lényeges vonása, hogy a dinamikus képesség főbb tulajdonságaival bír, és az elemzett vállalat szoftverkiadási folyamatában pozitív változásokat idéz elő. Elsőként jelentősen csökkenti a szoftverfejlesztés átfutási idejét a nem értéknövelő tevékenységek elhagyása révén. Másodsorban az észszerüsítés nagyban csökkenti a folyamat teljes költségét. Végül a szoros összehangolás megteremtése a szoftvermérnökök, a végfelhasználók és a projektmenedzser között a kiadási folyamat átfutási idejét és összköltségét tovább faragja. A bevezetés utáni időszak eredményei visszaigazolták, hogy a vállalat a Scrum révén sikeresen változtatta meg müködési logikáját, illetve piaci sikerességét és stratégiai mozgásterét egyaránt növelte. Ezt támasztja alá, hogy a vállalati menedzserek önkormányzatok, hírportálok, közüzemi és közlekedési szolgáltatók felé végbement sikeres diverzifikációs stratégiáról számoltak be. Az eredményeket alapul véve alátámasztjuk az elmélet egy lényeges elvárását (Winter, 2003; Helfat - Winter, 2011), amely szerint a dinamikus képességnek elő kell segítenie a cég jövedelemszerzésének sikeres megváltoztatását. Mivel az elemzett vállalat tagjai sikeresen sajátították el a Scrum alapelveit, így Zollo és Winter (2002) eredményeivel egyetértünk abban, hogy a dinamikus képességek tanulhatók, elsajátíthatók a szervezet tagjai által.

\section{Hozzájárulás a dinamikus képességek elméletéhez}

Az elmélet egyik eleme a vevőnek, végfelhasználónak nyújtott értékteremtés. A Scrum bevezetése lehetővé tette a vizsgált szervezetnek a pontos, határidőre nyújtott teljesítést. Ez egyértelmüen elégedettebbé tette nemcsak a folyamatban részt vállaló szoftverfejlesztőket, hanem a végfelhasználókat is. A sprint befejezéséhez kötődő üzleti érték biztosítása egyben szigorú Scrum elvárás is, ezzel is elősegítve a vevők fizetési hajlandóságát (Schwaber - Beedle, 2002).

Az elméleten belül megfigyelhető két vonulat. Az egyik szerint a dinamikus képesség maga a versenyképességi előny forrásává tud válni (Teece et al., 1997). A 
másik azt vallja, hogy az alapul szolgáló vállalati beidegződések egy idő után helyettesíthetővé válnak, és ezáltal átültethető legjobb gyakorlattá alakulnak át, így nem szolgálja ezt a célt (Eisenhardt - Martin, 2000). Tanulmányunkban elemzett agilis Scrum módszertan elméleti alapjait Schwaber és Beedle rakták le 2002-ben megjelent könyvükben. A témával kapcsolatosan ezután több, más, széles körben hozzáférhető szakmai publikáció is született, ami miatt vállalati alkalmazásuk felfogható egyfajta legjobb gyakorlatnak. Mégis, az általunk vizsgált üzleti vállalkozás a Scrum bevezetéséből versenyképességi elönyt tudott kovácsolni. Következésképpen egyet értünk Peteraf et al. (2013) vélekedésével, amely szerint a dinamikus képességek ugyan több közös vonással bírhatnak (ilyenek például a nyilvános Scrum szabályok és alapelvek), de a sikeres alkalmazás jónéhány jellemvonása nem teljesen helyettesíthető, illetve a kiváltott teljesítménynövekedést nagyban meghatározza az adott szervezeti helyzet egyedi jellegzetességei. Teece (2014) egy későbbi munkájában kifejti, hogy maga a dinamikus képesség nem okvetlen elégséges a versenyképességi előny megszerzéséhez, hanem bizonyos erőforrások és a jó stratégia megléte elengedhetetlennek bizonyulhat e lényeges célhoz. Esetünkben, a felsővezetői figyelem és az állandó támogatása a sokszor akadályokkal teli észszerüsítési folyamatnak kulcs erőforrásává vált. Ehhez szervesen kapcsolódik a szervezeti erőforrások révén a fentebb vázolt termékportfólió-bővítő stratégia eredményes végrehajtása, amelyet a szakirodalom a szoftvercégek jellegzetes stratégiájaként tart számon (Giarratana, 2004; Giarratana - Fosfuri, 2007; Sebrek, 2015).

Stadler et al. (2013) fontos munkája a területen, a szóban forgó képességek két lényeges tulajdonságára világít rá. Egyfelől a dinamikus képességnek különböznie kell a képesség használatának a következményeitöl. Másfelöl, azok birtoklása pozitívan befolyásolja mind az erőforráshoz való hozzájutás, mind az erőforrás-fejlesztés sikerét. Stadlerék munkájához hasonlóan a mi vállalati esetünkben is egy technológia fémjelezte a dinamikus képességet, amely bevezetése előtt és után is statisztikai módszerek révén elemezni tudtuk a szoftverfejlesztési folyamat lényegi jellemzőit. Ezáltal maga a képesség elkülönül annak következményétől, elősegítve a tárgyilagos mérést. A Scrum technológiát jelent, mert (1) egy olyan módszertan, amely egyedi eszközök és eljárások révén célelérést szolgál, (2) gyakorlati készségek tudományos tanulmányozását teszi lehetővé és előíró tudást biztosít, (3) alapvető egysége az eljárás, amely a Nelson és Winter-i (1982) beidegződéssel rokon fogalom. Továbbá, esetünkben világosan el tudtuk különíteni a szoftver demo változatának elkészítését jelképező erőforráshoz való hozzájutást és annak továbbfejlesztését, amely a kiadási folyamat többi tevékenységét a késztermék elkészítéséig öleli fel. A demo változat elkészültét a(z) 3. (5.) táblázatban a kilences (nyolcas) esemény (Fejlesztői tesztelés hibamentes) jelzi.

\section{Módszertani megállapítások}

A vállalat átalakulását a többlépcsős akciókutatás (Lewin, 1946; Susman - Evered, 1978; Kamann - van
Nieulande, 2010) révén kísértük végig, melynek eredményeként meggyőződhettünk az új folyamat teljesítményre gyakorolt pozitív hatásában - ahogy azt a dinamikus képesség elmélete megállapítja (Enríquez-De-La-O, 2015; Helfat et al., 2007; Pezeshkan et al., 2016; Teece, 2007). Munkánk során valós vállalati adatokat szakértői becsléseket is felhasználva szimulációs módszer segítségével elemeztük. A korábbi, a kívánatos és a bevezetett folyamatokat statisztikai eljárással hasonlítottuk össze. Ennélfogva Zott (2003) szimulációs és Danneels (2011) esettanulmányát ötvözzük, hogy a célvállalat átalakulási folyamatát megragadhassuk. A feltárt vállalati eset igazodik Teece $(2007,2014)$ munkáihoz abban, hogy a kiemelkedő dinamikus képességgel bíró vállalatokat vállalkozói szemlélet hatja át. Továbbá tanulmányunk eleget tesz Teece (2012) felhívásának, amely szerint a dinamikus képesség tetten érése nem csupán nagyminták alkalmazása által célravezető (például Helfat, 1997; Drnevich - Kriauciunas, 2011), hanem mélyreható esetleírás megvalósításával is (például Danneels, 2011).

\section{Következtetések a vállalatvezetők számára}

Munkánk gyakorló vállalatvezetők számára is szolgál hasznosítható tapasztalatokkal. Dinamikus képességre csak tudatos, fárasztó és hosszú folyamat révén lehet szert tenni. Ezen összetett stratégiai képesség építési és megújítási munka során nagyfokú türelmet kell gyakorolni a folyamatban részt vevő összes érintettel. Mindemellett a vezetésnek kiemelkedő figyelmet és állandó támogatást kell biztosítania az átalakulási folyamatot támogató és végrehajtó alkalmazottak számára, valamint egészséges légkört kell megteremteni a tanulási folyamat elősegítésére és a keletkező szervezeti ellenállás és tehetetlenség leküzdésére. Cikkünk így a magyar vállalati növekedés problémáit leíró szakirodalomhoz (lásd Reszegi - Juhász, 2017) is hozzájárul.

\section{Jövőbeli kutatási irányok}

A fentiek alapján úgy véljük, hogy a területen végzendő jövőbeli munkák gondot fordíthatnának a vállalatok figyelemalapú elmélete (Ocasio, 1997; Yu - Engleman - Van de Ven, 2005) és a dinamikus képességek közös alkalmazására. A figyelemalapú hagyomány több ízben tanulmányozott olyan vállalati eseteket, amelyeknél valamely külső esemény komolyan korlátozta egyes belső kulcseseményekre háruló figyelmet (Hoffman - Ocasio, 2001; Cho - Hambrick, 2006). Hasonló részletes, adatokkal alátámasztott tanulmány a dinamikus képességek felfejlesztésére is kiválóan illene. Egy másik érdekes terület a dinamikus képességek részletes tanulmányozására a nyílt innováció (Chesbrough, 2003; Laursen - Salter, 2006) lencséjén keresztül valósulhatna meg. Jelen esetben egyetemi kutatói szakmai segítséggel valósult meg a Scrum módszertan kiválasztása és bevezetése, amelyben a felhasználó is tevékenyen részt vett. Ezen túlmenően maga a Scrum tudásanyaga nyílt, bárki számára hozzáférhető. Véleményünk szerint e jellemzők keretbe foglalása érdekes jövőbeli kutatási irányt vetít elő. 


\section{Felhasznált irodalom}

Aranyossy M. - Blaskovics B. - Horváth A. A. (2015): Információtechnológiai projektek sikere és kudarca. Nemzetközi tapasztalatok és hazai kutatási eredmények. Vezetéstudomány/Budapest Management Review, 46(5), p. 66-78.

Augier, M. - Teece, D. J. (2008): Strategy as evolution with design: The foundations of dynamic capabilities and the role of managers in the economic system. Organization Studies, 29(8-9), p. 1187-1208.

Barnhart, R. K. - Steinmetz, S. (eds.) (1986): Hammon Barnhardt Dictionary of Science. Maplewood, New Yersey: Hammond Inc.

Bohl, P. (2015): Dynamic capabilities and strategic paradox: A case study. Vezetéstudomány/Budapest Management Review, 46(11), p. 25-38.

Chesbrough, H. W. (2003): Open innovation. Cambridge, MA.: Harvard University Press

Cho, T. S. - Hambrick, D. C. (2006): Attention as the mediator between top management team characteristics and strategic change: The case of airline deregulation. Organization Science, 17(4), p. 453-469.

Danneels, E. (2011): Trying to become a different type of company: Dynamic capability at Smith Corona. Strategic Management Journal, 32(1), p. 1-31.

Dingsøyr, T. - Nerur, S. - Balijepally, V. - Moe, N. B. (2012): A decade of agile methodologies: Towards explaining agile software development. Journal of Systems and Software, 85(6), p. 1213-1221.

Dobrev, S. D. - Kim, T. Y. - Carroll, G. R. (2002): The evolution of organizational niches: US automobile manufacturers, 1885-1981. Administrative Science Quarterly, 47(2), p. 233-264.

Drnevich, P. L. - Kriauciunas, A. P. (2011): Clarifying the conditions and limits of the contributions of ordinary and dynamic capabilities to relative firm performance. Strategic Management Journal, 32(3), p. 254-279.

Durlauf, S. N. - Blume, L. E. (eds.) (2008): New Palgrave Dictionary of Economics (Volume 8). Basingstoke: Macmillan Publishers

Ehrilch, E. et al. (1980): Oxford American Dictionary. Oxford: Oxford University Press

Eisenhardt, K. M. - Martin, J. A. (2000): Dynamic capabilities: What are they? Strategic Management Journal, 21(10-11), p. 1105-1121.

Enriquez de la O, J. F. (2015): Resource-based view and dynamic capabilities: Achieving competitive advantage through internal resources and competences. Vezetéstudomány/Budapest Management Review, 46(11), p. 50-61.

Fekri, R. - Aliahmadi, A. - Fathian, M. (2009): Identifying the cause and effect factors of agile NPD process with fuzzy DEMATEL method: The case of Iranian companies. Journal of Intelligent Manufacturing, 20(6), p. 637-648.

Giarratana, M. S. (2004): The birth of a new industry: Entry by start-ups and the drivers of firm growth: The case of encryption software. Research Policy, 33(5), p. 787-806.
Giarratana, M. S. - Fosfuri, A. (2007): Product strategies and survival in Schumpeterian environments: Evidence from the US security software industry. Organization Studies, 28(6), p. 909-929.

Gylling, M. - Heikkilä, J. - Jussila, K. - Saarinen, M. (2015): Making decisions on offshore outsourcing and backshoring: A case study in the bicycle industry. International Journal of Production Economics, 162, p. 92-100.

Helfat, C. E. (1997): Know-how and asset complementarity and dynamic capability accumulation: The case of R\&D. Strategic Management Journal, 18(5), p. 339360.

Helfat, C. E. - Finkelstein, S. - Mitchell, W. - Peteraf, M. A. - Singh, H. - Teece, D. J. - Winter, S. G. (2007): Dynamic capabilities: Understanding strategic change in organizations. Malden, MA.: Blackwell

Helfat, C. E. - Peteraf, M. A. (2015): Managerial cognitive capabilities and the microfoundations of dynamic capabilities. Strategic Management Journal, 36(6), p. 831-850.

Helfat, C. E. - Winter, S. G. (2011): Untangling dynamic and operational capabilities: Strategy for the $(\mathrm{N})$ ever-changing world. Strategic Management Journal, 32(11), p. 1243-1250.

Hoffman, A. J. - Ocasio, W. (2001): Not all events are attended equally: Toward a middle-range theory of industry attention to external events. Organization Science, 12 (4), p. 414-434.

Iansiti, M. - Clark, K. B. (1994): Integration and dynamic capability: Evidence from product development in automobiles and mainframe computers. Industrial and Corporate Change, 3(3), p. 557-605.

Kamann, D. J. - van Nieulande, V. (2010): A four-filter method for outsourcing to low-cost countries. Journal of Supply Chain Management, 46(2), p. 64-79.

Katkalo, V. S. - Pitelis, C. N. - Teece, D. J. (2010): Introduction: On the nature and scope of dynamic capabilities. Industrial and Corporate Change, 19(4), p. 11751186.

Kosztyán Zs. T. (2013): Projekttervezési módszerek kihívásai a XXI. században. Vezetéstudomány/Budapest Management Review, 44(9), p. 62-80.

Kosztyán, Zs. T. (2015): Exact algorithm for matrix-based project planning problems. Expert Systems with Applications, 42(9), p. 4167-4610.

Lancaster, K. (1990): The economics of product variety: A survey. Marketing Science, 9(3), p. 189-206.

Laursen, K. - Salter, A. (2006): Open for innovation: The role of openness in explaining innovation performance among U.K. manufacturing firms. Strategic Management Journal, 27(2), p. 131-150.

Lewin, K. (1946): Action research and minority problems. Journal of Social Issues, 2(4), p. 34-46.

Li, S. X. - Greenwood, R. (2004): The effect of withinindustry diversification on firm performance: Synergy creation, multi-market contact and market structuration. Strategic Management Journal, 25(12), p. 11311153. 
Lobo, S. - Whyte, J. (2017): Aligning and reconciling: Building project capabilities for digital delivery. Research Policy, 46(1), p. 93-107.

Nelson, R. - Winter, S. (1982): An evolutionary theory of economic change. Cambridge, MA.: Harvard University Press

Nicholls, G. M. - Lewis, N. A. - Eschenbach, T. (2015): Determining When Simplified Agile Project Management Is Right for Small Teams. Engineering Management Journal, 27, p. 3-10.

Ocasio, W. (1997): Towards an Attention-Based View of the Firm. Strategic Management Journal, 18 (Summer Special Issue), p. 187-206.

Peteraf, M. - Di Stefano, G. - Verona, G. (2013): The elephant in the room of dynamic capabilities: Bringing two diverging conversations together. Strategic Management Journal, 34(12), p. 1389-1410.

Pezeshkan, A. - Fainshmidt, S. - Nair, A. - Frazier, M. L. - Markowski, E. (2016): An empirical assessment of the dynamic capabilities-performance relationship. Journal of Business Research, 69(8), p. 2950-2956.

Reszegi L. - Juhász, P. (2017): Gátak a magyar vállalati növekedésben. Vezetéstudomány/Budapest Management Review, 48(6-7), p. 27-38. DOI https://doi. org/10.14267/VEZTUD.2017.06.04

Ross, A. - Buffa, F. P. - Dröge, C. - Carrington, D. (2006): Supplier evaluation in a dyadic relationship: An action research approach. Journal of Business Logistics, 27(2), p. 75-101.

Schwaber, K. - Beedle, M. (2002): Agile software development with Scrum. Upper Saddle River: Prentice Hall

Sebrek, S. S. (2015): Managing organisations in Schumpeterian environments: Intra-industry diversification through strategic technology alliances and patents. Technology Analysis \& Strategic Management, 27(2), p. 161-181.

Siggelkow, N. (2003): Why Focus? A study of intra-industry focus effects. The Journal of Industrial Economics, 51(2), p. 121-150.

Simpson, J. - Weiner, E. S. (1989): Oxford English dictionary (second edition). Oxford: Clarendon Press

Stadler, C. - Helfat, C. E. - Verona, G. (2013): The impact of dynamic capabilities on resource access and development. Organization Science, 24(6), p. 1782-1804.

Standish Group International Inc. (2016). Chaos Manifesto. Technical report.
Susman, G. I. - Evered, R. D. (1978): An assessment of the scientific merits of action research. Administrative Science Quarterly, p. 582-603.

Szabó Zs. R. (2012): Bizonytalanság, stratégia és teljesítmény - Kvalitatív kutatás innovatív kis-és középvállalatok vezetöi körében. Vezetéstudomány/Budapest Management Review, 43(12), p. 23-30.

Tarek, K. A-H. (1993): A multiproject perspective of single-project dynamics. Journal of Systems and Software, 22(3), 1993, p. 151-165.

Teece, D. J. (2007): Explicating dynamic capabilities: The nature and microfoundations of (sustainable) enterprise performance. Strategic Management Journal, 28(13), p. 1319-1350.

Teece, D. J. (2012): Dynamic capabilities: Routines versus entrepreneurial action. Journal of Management Studies, 49(8), p. 1395-1401.

Teece, D. J. (2014): The foundations of enterprise performance: Dynamic and ordinary capabilities in an (economic) theory of firms. Academy of Management Perspectives, 28(4), p. 328-352.

Teece, D., - Pisano, G. (1994): The dynamic capabilities of firms: An introduction. Industrial and Corporate Change, 3(3), p. 537-556.

Teece, D. J. - Pisano, G. - Shuen, A. (1997): Dynamic capabilities and strategic management. Strategic Management Journal, 18(7), p. 509-533.

Winter, S. G. (2003): Understanding dynamic capabilities. Strategic Management Journal, 24(10), p. 991-995.

Wysocki, R. K. (2012): Effective project management, traditional, agile, extreme. Chichester: Wiley

Yu, J. - Engleman, R. M. - Van de Ven, A. H. (2005): The integration journey: An attention-based view of the merger and acquisition integration process. Organization Studies, 26(10), p. 1501-1528.

Yuan, C. - Li, Y. - Vlas, C. O. - Peng, M. W. (2018): Dynamic capabilities, subnational environment, and university technology transfer. Strategic Organization, 16(1), p. 35-60.

Zollo, M. - Winter, S. G. (2002): Deliberate learning and the evolution of dynamic capabilities. Organization Science, 13(3), 339-351.

Zott, C. (2003): Dynamic capabilities and the emergence of intraindustry differential firm performance: Insights from a simulation study. Strategic Management Journal, 24(2), p. 97-125. 